Ann. Biol. anim. Bioch. Biophys., 1979, 19 (6), 1677-1688.

\title{
Effect of different modifications of a semi-synthetic diet on bile acid metabolism in axenic and holoxenic rats
}

\author{
E. SACQUET, C. LEPRINCE, M. RIOTTOT
}

Laboratoire des animaux sans germes du C. N. R. S., I. N. R. A., 78350, jouy-en-josas.

Summary. Axenic (germfree) and holoxenic (conventional) rats were fed diets which were different as to $(a)$ the mode of sterilization : autoclaving or gamma-irradiation ; (b) the absence or presence of 10 p. 100 lactose added before sterilization. In addition, the autoclaved diet was offered to the rats in the form of pellets and the irradiated diet in the form of a paste. Important changes in bile acid metabolism were induced by these dietary modifications.

1) The bile acid infestinal pools were much larger in the rats fed the irradiated diet than in those fed the autoclaved one. They were unmodified by the addition of lactose when the diet was irradiated, but increased when it was autoclaved. The variations were observed both in axenic and holoxenic rats, and are therefore considered as not mediated by the intestinal bacterial flora.

2) Bile acid fecal excretions varied conversely to the pools.

3) In axenic rats, the percentage of cholic acid decreased when the bile acid pool increased.

4) In holoxenic rats, the bacterial transformation of bile acids was lower with the irradiated diet than with the autoclaved diet, and with the lactose-containing diet than with the lactose-free one. The formation of $\omega$-muricholic acid at the expense of hyodeoxycholic acid increased when the bacterial transformation of bile acids decreased.

Hypotheses are proposed to explain these variations in bile acid metabolism induced by the diet.

Daily fecal excretion and distribution of bile acids within the small intestine, cecum and large intestine are greatly modified by the presence or absence of a microbial flora in the digestive tract as well as by the composition of the diet (Kellog, 1971, 1974 ; Wostmann, 1973 ; Balmer and Zilversmit, 1974 ; Sacquet et al., 1975, $1977 a$; Mathé et al., 1977).

In order to investigate which dietary factors are involved and their mechanism of action, we have undertaken to modify a semi-synthetic diet gradually and to observe the resulting variations in bile acid metabolism.

In this paper we describe the findings obtained in axenic and holoxenic rats fed 
a semi-synthetic diet sterilized either by autoclaving or by gamma irradiation and containing 10 p. 100 lactose or not. The autoclaved diet was given in the form of pellets, and the irradiated diet in the form of paste containing 50 p. 100 water.

A similar study was published by Wostmann et al. (1976-1977) during the achievement of our investigation. As there are very large differences between their results and ours, it seems appropriate to give a complete description of our work.

\section{Materials and methods.}

A total of 8 experimental groups (GFI, GFLI, GFAu, GFLAu, CVI, CVLI, CVAu, CVLAu)* were compared. The GFAu and CVAu groups were used in a previous experiment (Sacquet ef al., 1977a) in which they were called SN-A and SN-H, respectively. Except for the few details mentioned below, the basic diets, rats and analytical methods were similar to those of the previous experiments. They have been described completely in a recent work (Sacquet ef al., 1978a).

Male Fischer inbred rats were used. The basic diet contained $220 \mathrm{~g}$ casein, $580 \mathrm{~g}$ maize starch, $90 \mathrm{~g}$ maize oil, $50 \mathrm{~g}$ cellulose, $45 \mathrm{~g}$ mineral and vitamin mixture. When this diet was to be sterilized by autoclaving, it was admixed with $200 \mathrm{~g}$ water and pressed; when it was to be irradiated, no water was added and it was introduced into vacuum-sealed polyethylene bags and then irradiated at 4 megarads. The rats were fed the experimental diets ad libitum for two months. The feces were then collected for seven days and the rats were killed. The holoxenic animals were maintained in conditions similar to their axenic homologues, except that they were not kept in isolators, but in an animal room. Bile acid was analyzed by the method of isotopic equilibrium of ${ }^{4-14} \mathrm{C}$ cholesterol. The different chemical species of bile acids were separated by thin-layer chromatography on silicagel $G$ by means of a chloroform-acetone-methanol (70/25/5) mixture. Results were expressed by the arithmetic mean of each group and the standard deviation of the mean. The different groups were compared using a three-way variance analysis (Scheffe, 1959). The three factors were microbial flora $(F)$, mode of sterilization (S), lactose (L). In the case of cecal weights, because of the outstanding effect of bacterial flora a two-way analysis $(L, S)$ was also carried out within the GF group on one hand and the CV group on the other.

\section{Results.}

Table 1 shows the age, body weight and cecum weight of the rats, and table 2 presents the results of the statistical analysis of cecum weights. The cecum weight was higher in axenic than in holoxenic rats and in those fed an autoclaved diet than in those fed an irradiated one. The presence of lactose did not affect the cecum weight in axenic rats, while it increased that weight in holoxenic rats, especially those fed the autoclaved diet (interaction $L \times S$ ).

* GF : axenic (germfree) ; CV : holoxenic (conventional) ; I : irradiated diet ; Au : autoclaved diet ; $L$ : diet containing 10 p. 100 lactose. 
TABLE 1

Age, body weight, cecal weight per $100 \mathrm{~g}$ body weight of axenic and holoxenic rats fed the different diets. Mean \pm standard deviation of the mean of 4 rats

\begin{tabular}{|c|c|c|c|c|}
\hline Microbial status & $\operatorname{Diet}\left({ }^{1}\right)$ & Age & Body weight & $\begin{array}{c}\text { Cecal weight } / 100 \mathrm{~g} \text { body } \\
\text { weight }\left({ }^{2}\right)\end{array}$ \\
\hline \multirow{5}{*}{$\begin{array}{l}\text { Axenic } \\
\mathrm{GF}\end{array}$} & & days & $g$ & p. 100 \\
\hline & $1 \ldots \ldots$ & 130 & $321 \pm 13.1$ & $6.7 \pm 0.22$ \\
\hline & LI........ & 129 & $296 \pm 2.7$ & $6.6 \pm 0.38$ \\
\hline & Au $\ldots \ldots$ & 113 & $269 \pm 7.6$ & $9.1 \pm 0.36$ \\
\hline & $\overline{L A U} \ldots \ldots$ & 125 & $309 \pm \overline{7.5}$ & $9.8 \pm 1.35$ \\
\hline \multirow{4}{*}{$\begin{array}{l}\text { Holoxenic } \\
\mathrm{CV}\end{array}$} & I $\ldots \ldots$ & 114 & $310 \pm 3.1$ & $1.0 \pm 0.04$ \\
\hline & $\mathrm{LI} \ldots \ldots$. & 127 & $303 \pm 6.7$ & $1.6 \pm 0.10$ \\
\hline & Au $\ldots . .$. & 103 & $250 \pm 5.0$ & $1.6 \pm 0.09$ \\
\hline & $\overline{L A u} \ldots \ldots$ & 119 & $291 \pm 3.2$ & $2.8 \pm 0.07$ \\
\hline
\end{tabular}

(1) $\mathrm{I}=$ irradiated, $A u=$ autoclaved, $L=10$ p. 100 lactose.

$\left({ }^{2}\right)$ Analysis of variance of cecal weight see table 2.

TABLE 2

Analysis of variance of cecal weights

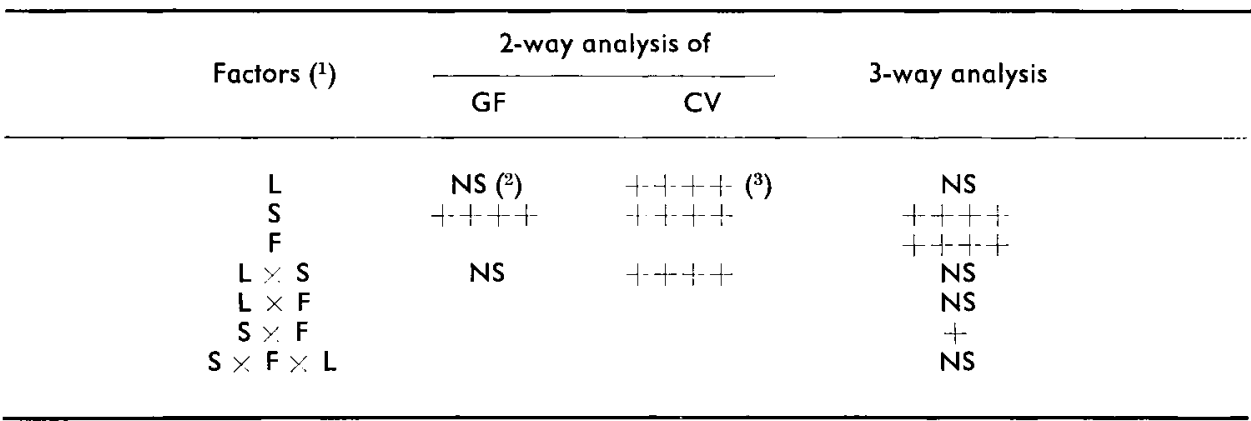

( $\left.{ }^{1}\right) \mathrm{L}=$ lactose ; $\mathrm{S}=$ mode of sterilization ; $\mathrm{F}:=$ microbial flora ; $X=$ interaction.

$\left.{ }^{2}\right)$ NS $=$ non significant.

$\left({ }^{3}\right)++++$ significant, $p<0,5$ p. $100 ;++-+$ significant, $p<1$ p. $100 ;-+$ significant, $p<2,5$ p. $100 ;+$ significant, $p<5$ p. 100.

Table 3 shows the amounts of bile acids in the small intestine, the cecum and the colon together as well as daily fecal excretion ; table 4 presents the results of the analysis of variance. The small intestine of axenic rats contained twice as much bile acids as that of holoxenic rats receiving the same diet. The different diets had similar effects 
in axenic and holoxenic rats. The rats fed a lactose-free irradiated diet had twice as much bile acids in the small intestine as those fed an autoclaved diet (GFI vs GFAu, CVI vs CVAu). The presence of lactose had no effect when the diet was irradiated;

TABLE 3

Daily fecal excretion and amounts of bile acids in the small intestine, cecum and large intestine expressed in $\mu$ moles per $100 \mathrm{~g}$ body weight. Mean \pm standard deviation of the mean of 4 rats ${ }^{(1)}$

\begin{tabular}{|c|c|c|c|c|c|}
\hline $\begin{array}{l}\text { Microbial } \\
\text { status }\end{array}$ & Diets $\left({ }^{2}\right)$ & $\begin{array}{c}\text { Small } \\
\text { intestine }\end{array}$ & $\underset{\text { large intestine }}{\text { Cecum }+}$ & $\begin{array}{l}\text { Total } \\
\text { Pool }\end{array}$ & $\begin{array}{c}\text { Fecal } \\
\text { excretion }\end{array}$ \\
\hline \multirow{4}{*}{$\begin{array}{c}\text { Axenic } \\
\text { GF }\end{array}$} & I $\ldots \ldots \ldots$ & $84.0 \pm 4.1$ & $21.6 \pm 1.02$ & $105.6 \pm 4.8$ & $7.1 \pm 0.33$ \\
\hline & LI $\ldots . . .$. & $89.8 \pm 1.1$ & $11.4 \pm 1.3$ & $101.1 \pm 1.2$ & $5.7 \pm 0.17$ \\
\hline & Au $\ldots \ldots \ldots$ & $39.2 \pm 1.2$ & $25.0 \pm 1.1$ & $64.2 \pm 3.4$ & $9.8 \pm 0.45$ \\
\hline & $\overline{\text { LAu }} \quad \ldots \ldots$ & $69.9 \pm 5.2$ & $17.8 \pm 4.4$ & $87.7 \pm 7.6$ & $6.0 \pm 0.22$ \\
\hline \multirow{4}{*}{$\begin{array}{l}\text { Holoxenic } \\
\text { CV }\end{array}$} & I.......... & $45.4 \pm 2.9$ & $10.6 \pm 2.2$ & $56.0 \pm 1.1$ & $10.2 \pm 0.30$ \\
\hline & LI $\quad \ldots \ldots \ldots$ & $49.4 \pm 1.2$ & $11.9 \pm 2.2$ & $61.3 \pm 1.8$ & $11.8 \pm 0,93$ \\
\hline & $A \cup \ldots \ldots \ldots$ & $22.7 \pm 1.2$ & $11.6 \pm 0.5$ & $34.3 \pm 1.6$ & $12.9 \pm 0.90$ \\
\hline & LAu $\ldots$ & $29.3 \pm 3.6$ & $23.4 \pm 4.5$ & $52.7 \pm 3.5$ & $12.1 \pm 0.80$ \\
\hline
\end{tabular}

(1) Statistical analysis : see table 4.

(2) Same meaning as in table 1.

it increased the bile acid pool of the small intestine when the diet was autoclaved (interaction $L \times S$ ), but this increase was only significant in axenic rats (interaction $S \times F \times L)$.

TABLE 4

Three-way analysis of variance of bile acid intestinal pools and fecal excretion

\begin{tabular}{ccccc}
\hline Factors ( $\left.{ }^{\mathbf{1}}\right)$ & $\begin{array}{c}\text { Small } \\
\text { intestine }\end{array}$ & $\begin{array}{c}\text { Cecum }+ \text { large } \\
\text { intestine }\end{array}$ & $\begin{array}{c}\text { Total } \\
\text { pool }\end{array}$ & $\begin{array}{c}\text { Fecal } \\
\text { excretion }\end{array}$ \\
\hline $\mathbf{L}$ & ++++ & NS & ++++ & ++ \\
\hline $\mathbf{S}$ & ++++ & ++++ & ++++ & ++++ \\
\hline $\mathbf{F}$ & ++++ & ++++ & ++++ & ++++ \\
\hline $\mathbf{L} \times \mathbf{S}$ & +++ & NS & ++++ & ++ \\
\hline $\mathbf{L} \times \mathbf{F}$ & +++ & ++++ & NS & ++++ \\
\hline $\mathbf{S} \times \mathbf{F}$ & ++ & NS & + & NS \\
\hline $\mathbf{S} \times \mathbf{F} \times \mathbf{L}$ & ++ & NS & NS & NS \\
\hline
\end{tabular}

(1) Same meaning as in table 2. 
The bile acid pool of the cecum and the large intestine also showed great variations. In holoxenic rats it was twice as high in LAu rats as in the three other groups, and in axenic rats it was lower in LI rats than in the other groups (interaction $F \times L$ ). As a result of these variations of the bile acid pools of the cecum and large intestine, the total pool presented a strong $L \times S$ interaction and no $L \times F$ interaction : the

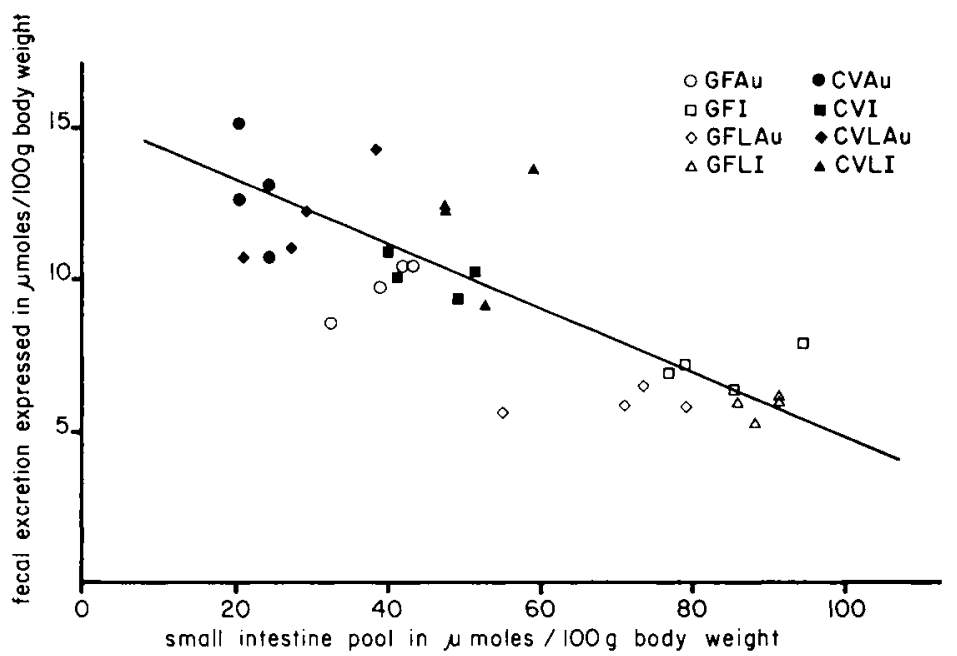

FIG. 1. - Relationship befween bile acid fecal excretion and small intestine pool (Individual values of the 32 rats distributed into 8 experimental lots).

presence of lactose largely increased the total pool in the rats which were fed the autoclaved diet, but there was no change in the rats which were fed the irradiated diet. The other variations of this total pool were similar to those of the pool of the small infestine.

The fecal excretion of bile acids varied conversely to the pool of the small intestine or to the total pool of bile acids (fig. 1). For the first one $y=-0.097 x+14.7$,

\section{TABLE 5}

Percent average composition of bile acids in the small intestine of axenic rats fed the different diets. Mean \pm standard deviation of the mean of 4 rats

\begin{tabular}{|c|c|c|c|c|}
\hline Diets & 1 & LI & Au & LAu \\
\hline Acids : & p. 100 & p. 100 & p. 100 & p. 100 \\
\hline 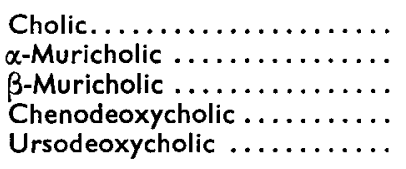 & $\begin{aligned} 25.5 & \pm 1.2 \\
3.0 & \pm 0.1 \\
56.4 & \pm 0.8 \\
1.7 & \pm 0.2 \\
1,8 & \pm 0.1\end{aligned}$ & $\begin{aligned} 27.6 & \pm 1.2 \\
2.5 & \pm 0.1 \\
51.6 & \pm 1.4 \\
1.2 & \pm 0.2 \\
1,3 & \pm 0,3\end{aligned}$ & $\begin{aligned} 36.2 & \pm 1.0 \\
4.6 & \pm 0.4 \\
38.9 & \pm 0.5 \\
4.7 & \pm 0.2 \\
2.8 & \pm 0.2\end{aligned}$ & $\begin{aligned} 29.8 & \pm 1.0 \\
2.7 & \pm 0.33 \\
47.7 & \pm 1.8 \\
1.4 & \pm 0.2 \\
1.4 & \pm 0.3\end{aligned}$ \\
\hline Undetermined ............ & 11.7 & 15.8 & 12.3 & 17 \\
\hline
\end{tabular}


$r=0.81$, where $y$ is the fecal excretion and $x$ the pool, and for the second one $y=-0.095 x+16.2, r=0.82$.

The different diets also modified the bile acid composition of both the intestinal contents and the feces. In axenic rats (tables 5 and 6) the Au group showed a higher

\section{TABLE 6}

Percent average composition of bile acids in the feces of axenic rats fed the different diets. Mean \pm standard deviation of the mean of 4 rats

\begin{tabular}{|c|c|c|c|c|}
\hline Diets & $\mathbf{1}$ & LI & Au & LAu \\
\hline Acids : & p. 100 & p. 100 & p. 100 & p. 100 \\
\hline 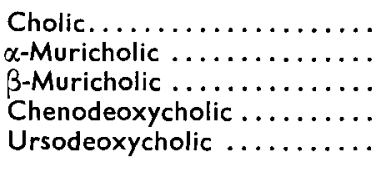 & $\begin{aligned} 14.2 & \pm 0.5 \\
3.4 & \pm 0.1 \\
45.2 & \pm 0.8 \\
1.8 & \pm 0.2 \\
1.4 & \pm 0.1\end{aligned}$ & $\begin{aligned} 12.1 & \pm 0.4 \\
3.6 & \pm 0.3 \\
47.9 & \pm 1.0 \\
1.3 & \pm 0.1 \\
1.8 & \pm 0.02\end{aligned}$ & $\begin{array}{r}22.4 \pm 3.9 \\
4.6 \pm 0.2 \\
37.4 \pm 0.6 \\
3.5 \pm 0.2 \\
2.5 \pm 0.1\end{array}$ & $\begin{array}{r}12.3 \pm 0.4 \\
3.5 \pm 0.3 \\
50.0 \pm 0.4 \\
1.3 \pm 0.07 \\
1.5 \pm 0.07\end{array}$ \\
\hline Undetermined............. & 34.1 & 33.3 & 30.6 & 31.4 \\
\hline
\end{tabular}

percentage of cholic acid than the other three groups, I, LI and LAu, where this percentage was similar. The same observation could not be made in holoxenic rats because of the complex bile acid composition created by the bacterial metabolism. In the small intestine (table 7), where composition was simpler than in the feces, the cholic + deoxycholic sum was not substantially different in the four groups. In the feces of the CVAu rats, the total percentage of the acids synthesized by the organism

\section{TABLE 7}

Percent average composition of bile acids in the small infestine of holoxenic rats fed the different diets. Mean \pm standard deviation of the mean of 4 rats

\begin{tabular}{|c|c|c|c|c|}
\hline Diets & I & LI & Au & $\mathrm{LAu}$ \\
\hline Acids : & p. 100 & p. 100 & p. 100 & p. 100 \\
\hline 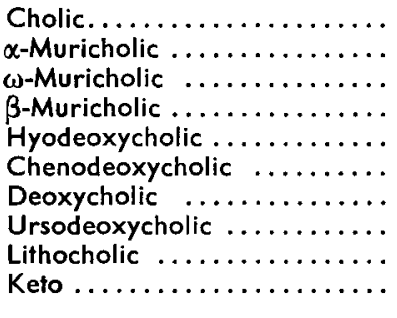 & $\begin{array}{r}40.5 \pm 0.8 \\
3.4 \pm 0.2 \\
3.0 \pm 0.2 \\
31.1 \pm 1.1 \\
6.8 \pm 0.6 \\
1.7 \pm 0.3 \\
1.2 \pm 0.2 \\
1.2 \pm 0.1 \\
0.9 \pm 0.1 \\
4.8 \pm 0.4\end{array}$ & $\begin{array}{l}40.0 \pm 0.4 \\
2.8 \pm 0.2 \\
3.6 \pm 0.2 \\
34.7 \pm 0.9 \\
0.6 \pm 0.05 \\
1.7 \pm 0.1 \\
1.1 \pm 0.1 \\
1.9 \pm 0.1 \\
1.7 \pm 0.1 \\
6.0 \pm 0.5\end{array}$ & $\begin{array}{r}35.2 \pm 1.2 \\
4.8 \pm 0.2 \\
2.2 \pm 0.3 \\
21.2 \pm 0.7 \\
10.4 \pm 0.3 \\
4.6 \pm 0.3 \\
4.5 \pm 0.5 \\
2.2 \pm 0.1 \\
1.1 \pm 0.2 \\
7.1 \pm 1.5\end{array}$ & $\begin{array}{r}40.6 \pm 1.8 \\
3.7 \pm 0.3 \\
3.9 \pm 0.6 \\
27.0 \pm 0.6 \\
5.4 \pm 2.0 \\
1.8 \pm 0.1 \\
2.2 \pm 0.3 \\
1.8 \pm 0.2 \\
1.3 \pm 0.1 \\
6.1 \pm 0.6\end{array}$ \\
\hline Undetermined $\ldots \ldots \ldots \ldots \ldots$ & 5.4 & 5.9 & 6.7 & 6.0 \\
\hline
\end{tabular}


and detectable by chromatography (cholic, $\alpha$-muricholic, $\beta$-muricholic, chenodeoxycholic) was very low (less than 6 p. 100), while the proportion of bacterial metabolites, such as the unknown bile acid 4b, hyodeoxycholic, deoxycholic, lithocholic acids, as well as the various ketocholanic acids, was very high. There was very little $\omega$-muricholic acid. In the CVI group, a larger amount of primary bile acids (17 p. 100) : was unmodified by bacterial metabolism, and the percentage of $\omega$-muricholic acid increased. Under the influence of lactose (CVLI compared to CVI, CVLAu compared to CVAu) these trends became more pronounced: the bacterial transformation decreased and the $\omega$-muricholic acid percentage increased while that of bile acid $4 \mathrm{~b}$ and hyodexycholic acid decreased.

\section{TABLE 8}

Percent average composition of bile acids in the feces of holoxenic rats fed the different diets. Mean \pm standard deviation of the mean of 4 rats

\begin{tabular}{|c|c|c|c|c|}
\hline Diets & I & LI & $\mathrm{Au}$ & LAu \\
\hline Acids : & p. 100 & p. 100 & p. 100 & p. 100 \\
\hline 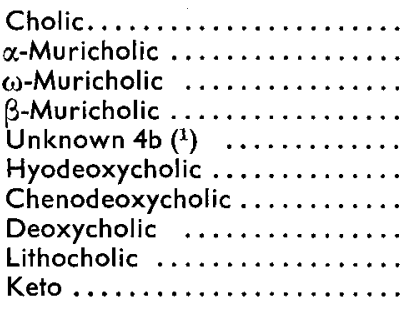 & $\begin{array}{r}3.8 \pm 0.2 \\
3.4 \pm 0.2 \\
8.2 \pm 0.7 \\
8.7 \pm 0.5 \\
5.2 \pm 0.3 \\
20.4 \pm 0.7 \\
1.2 \pm 0.1 \\
7.2 \pm 0.2 \\
4.7 \pm 0.1 \\
27.5 \pm 0.6\end{array}$ & $\begin{aligned} 4.2 & \pm 0.3 \\
9.6 & \pm 0.4 \\
31.4 & \pm 1.2 \\
9.7 & \pm 0.6 \\
1.4 & \pm 0.2 \\
1.2 & \pm 0.1 \\
6.2 & \pm 0.5 \\
5.3 & \pm 0.4 \\
20.7 & \pm 1.2\end{aligned}$ & $\begin{array}{r}1.3 \pm 0.2 \\
2.0 \pm 0.2 \\
3.1 \pm 0.6 \\
1.5 \pm 0.2 \\
7.2 \pm 0.3 \\
22.7 \pm 0.5 \\
1.0 \pm 0.3 \\
13.4 \pm 0.7 \\
9.4 \pm 0.2 \\
38.5 \pm 1.5\end{array}$ & $\begin{array}{r}2.5 \pm 0.2 \\
7.4 \pm 1.4 \\
20.2 \pm 4.6 \\
6.6 \pm 0.6 \\
4.6 \pm 1.0 \\
12.4 \pm 3.7 \\
0.9 \pm 0.1 \\
9.1 \pm 0.8 \\
4.5 \pm 0.5 \\
27.6 \pm 2.2\end{array}$ \\
\hline Undetermined. & 9.8 & 10.0 & 9.7 & 5.0 \\
\hline
\end{tabular}
1974).

(') Unknown bile acid related to hyodeoxycholic acid, (Van Heijenoort, Sacquet and Riottot,

\section{Discussion.}

Our results on variations in the cecum weight of holoxenic rats agree with those in the literature : increased cecum weight affected by lactose (Fischer, 1957 ; Fournier, Susbielle and Bescol-Liversac, 1959 ; Février and Rérat, 1964 ; Leegwater, de Groot and van Kalmont-Kuyper, 1974 ; Adrian and Frangne, 1978 ; Kim, Benevenga and Grummer, 1978 ; Pansu, Bellaton and Bosshard, 1978) as well as by the products of Maillard's reaction (Adrian, 1974). However, in the axenic rat there was novariation due to the action of lactose whether it was irradiated or autoclaved. This suggests that in holoxenic rats the action of LI or LAU operates through bacterial metabolites : lactic acid, volatile fatty acids, products of the premelanoildine transformation; etc... In addition, in axenic rats, the mode of sterilization or the physical form of the feed affected cecum distention ; there was therefore a direct effect of these dietary variations upon cecal enlargement, i.e. an action in which intestinal flora was not involved. 
There was no relationship between the cecum weight and the bile acid pool of the whole of the cecum and the large intestine. In holoxenic rats the LAu group exhibited both the heaviest cecum and the highest bile acid pool, but this was not the case in axenic rats. It is difficult to explain these variations. There are very little data in the literature concerning the bile acid pool of these organs, although they contain the largest part of the gastro-intestinal microbial flora, are the site of very active transformations of bile acids, and in some instances (e.g. CVLAu) contain almost as much bile acids as the small intestine. In their recent work, Wostmann ef al. do not study this pool.

These are large differences between Wostmann's results and ours. According to Wostmann et al. :

1) There was no noticeable difference between the rats fed diet $I$ and those fed diet Au as to the small intestine bile acid pool and fecal bile acid excretion.

2) $\mathrm{LI}$ as compared to I increased the intestinal pool in CV rats. It produced only slight modifications of the bile salt composition in GF and CV rats, and had no major effect on the metabolism of the bile acids.

3) LAu, on the contrary, had a large influence : in CV rats it produced a significant decrease of the fecal excretion of bile acids as well as a marked increase of the percentage of $\beta$-muricholic acid and of its derivates. The large increase in $\omega$-muricholic acid at the expense of hyodeoxycholic acid was only noticed in group CVLAu, not in CVLI. It was attributed by these authors to autoclaving of the diet and considered as resulting from an increased hepatic transformation of hyodeoxycholic acid into $\omega$-muricholic acid.

It is very difficult to understand the origin of such differences between the results of those authors and ours, as well as the extreme complexity of their results. On the contrary our results are very homogeneous and can probably be explained by simple hypotheses that we will verify in further studies.

Two mechanisms may explain the modifications of the bile acid pool of the small intestine : the transit time through the small intestine and the absorption rate of the bile acids in the ileum. We have already demonstrated that the transit time through the small intestine is longer in axenic than in holoxenic rats (Sacquet, Garnier, and Raibaud, 1970), while the absorption rate of sodium taurocholate in the ileum is almost the same in both groups (Riottot et al., 1975). The larger bile acid pool of GF rats results probably from this longer transit time. In the same way, the larger intestinal pool in I and LI rats may result from a lengthening of the transit time, which is liable to occur in CV as well as in GF rats under the action of these diets. A second mechanism which could explain the variations of the small intestine bile acid pool is the increase of the absorption rate of bile acids in the ileum. If we assume that the amount of bile acids which are not absorbed depends on the amount of bile acids arriving in the terminal part of the small intestine, the result is that for a given level of biosynthesis, the intestinal pool must increase when the ileal absorption rate increases. It has been already observed that dief LAu brings about a larger ileal absorption rate of sodium taurocholate than diet LI (Riottot ef al., 1977). This would explain why, at least in axenic rats, the bile acid pool of the small intestine is higher in LAu than in $\mathrm{LI}$ rats. 
Variations in fecal excretion seem to be largely due to feedback regulation of bile acid biosynthesis. A higher intestinal pool would determine a greater flow of bile acids through the liver, and accordingly a decrease in biosynthesis, leading to less fecal excretion of these bile acids. Thus the main characteristics of bile acid metabolism (fecal excretion and intestinal pool) seem to depend on changes in the transit time and the ileal absorption rate in the small intestine in connection with dietary factors, and the presence or absence of microflora.

In axenic rats, the decrease in the biosynthesis of cholic acid does not result from the presence or absence of lactose because it occurs not only in GFLI and GFLAU rats, but also in GFI rats, i.e. in all rats exhibiting high intestinal pools. These results suggest that $12 \alpha$-hydroxylase activity in also subjected to a feedback regulation. However there is no perfect parallelism befween the feedback regulation of the synthesis of all bile acids and that of cholic acid since the percentage of the latter decreases.

In holoxenic rats, it it impossible to estimate the percentage of biosynthesized cholic acid by measuring the fecal excretion of cholic and deoxycholic acids on the one hand and that of $\alpha-, \beta$-muricholic acids and their bacterial metabolites ( $\omega$-muricholic, hyodeoxycholic, lithocholic acids) on the other, as some authors (Wostmann et al., 1976, 1977) have done. There is in fact a large percentage of ketocholanic acids of undetermined composition, so that is is impossible to ascertain whether they are derived from cholic acid or muricholic acids. Though the compositions of the bile acids in the small intestine of holoxenic rats are much simpler than the fecal compositions, the percentage of biosynthesized cholic acid cannot be estimated on the basis of small infestine bile acid composition, since the various bile acids do not participate equally in the enterohepatic cycle because of different absorption rates. In particular, $\omega$-muricholic acid is almost absent in the small intestine, even when it is present in a very large quantity in the feces (CVLI, CVLAu).

Variations in the bacterial transformation of bile acids, as affected by different feeds, can be explained in a simple way if it is assumed that $\omega$-muricholic acid and hyodeoxycholic acid proceed from $\beta$-muricholic acid, that $\omega$-muricholic acid is formed by the action of a bacterial 6-isomerase which inverts the 63-hydroxyl of $\beta$-muricholic acid into $6 \alpha$, and that, in addition to the 6 -isomerase mentioned above, hyodeoxycholic acid requires a bacterial $7 \beta$-dehydroxylase according to the scheme :

$3 \alpha, 6 \beta, 7 \beta$-tri OH $\rightarrow 3 \alpha, 6 \alpha, 7 \beta$-tri OH $\rightarrow 3 \alpha, 6 \alpha$-di OH.

This theory is based upon different experimental findings (Van Heijenoort, Sacquet and Riottot, 1974 ; Sacquet et al., $1977 b$; Sacquet et al., 1978b). Accordingly the decrease in hydeoxycholic acid and the increase in $\omega$-muricholic acid correspond to a decrease in a bacterial enzymatic action, 7 $\beta$-dehydroxylation. But when comparing the fecal bile acid composition in groups CVAu, CVI, CVLAu and CVLI it appears that the formation of $\omega$-muricholic acid is accompanied by a decrease in all the other bacterial transformations of the bile acids. Thus all the changes observed in these groups in the fecal bile acid composition result from a decrease in the bacterial transformations.

Two processes may explain this event. The first one is suggested by a comparison between CVAu and CVI rats : autoclaving as compared to irradiation decreases the digestibility of the diet and allows material to arrive in the cecum where it is degraded and used by fecal bacteria. This causes an increase in bacterial proliferation and in the transformation of bile acids caused by the bacteria. The second process is suggested 
by the comparison between CVI and CVLI. Lactose is not altered by the gamma irradiation of the diet. In the cecum and large intestine it is subjected to lactic acid fermentation and the formation of volatile fatty acids. These acids may affect bile acid transformation in different ways : through their antibacterial action they may lead to the disappearance of numerous intestinal bacteria or, by changing the $\mathrm{pH}$, they may modify the activity of bacterial enzymes, as already demonstrated for the $7 \alpha$-dehydroxylases and $3 \alpha, 7 \alpha$ - and $12 \alpha$-dehydrogenases of bile acids (Aries and Hill, 1970).

The production of $\omega$-muricholic acid should lead to an increase in the fecal excretion of bile acids in the rats in which it is abundantly formed (CVLI and CVLAu), since this bile acid seems to be difficulf to absorb. This was observed in two groups of rats fed a similar diet but whose different flora produced $\omega$-muricholic acid in one group and hyodeoxycholic acid, as well as the unknown acid $4 b$ in the other group (Sacquet et al., 1977c). This was not observed in the present experiment. It may be that there are opposite actions in CVLI and CVLAu rats, and that the increased fecal excretion resulting from the formation of $\omega$-muricholic acid is compensated for by a process tending to decrease the biosynthesis of the bile acids, as for instance an increased flow of bile acids through the liver.

Reçu en avril 1979.

Accepté en avril 1979.

Acknowledgments. - This work was supported by a grant DGRST, no 77.7.0475 "Interaction between diet and the digestive tract".

We thank Mrs Bouroche for the English translation.

Résumé. Des rats axéniques ef des rats holoxéniques sont nourris à l'aide d'aliments qui diffèrent par $a$ ) leur mode de stérilisation - autoclavage ou irradiation gamma, $b$ ) la présence ou l'absence de 10 p. 100 de lactose ajouté avant stérilisation. De plus, l'aliment autoclavé esí présenté aux rats sous forme de comprimés et l'aliment irradié sous forme d'une pâte. Ces modifications alimentaires déterminent d'importants changements du métabolisme des acides biliaires :

1) Les pools intestinaux d'acides biliaires sont beaucoup plus importants chez les rats qui se nourrissent de l'aliment irradié que chez ceux qui reçoivent l'aliment autoclavé. Ces variations s'observent à la fois chez les rats axéniques ef chez les rats holoxéniques et en conséquence ne relèvent pas d'une action de la flore microbienne intestinale.

2) L'excrétion fécale d'acides biliaires varie d'une manière inverse du pool intestinal.

3) Chez les rats axéniques, le pourcentage d'acide cholique diminue quand le pool intestinal des acides biliaires augmente.

4) Chez les rats holoxéniques, la transformation bactérienne des acides biliaires est plus faible chez les sujets nourris à l'aide de l'aliment irradié que chez ceux qui reçoivent l'aliment autoclavé et chez les rats qui reçoivent l'aliment lactosé que chez ceux dont l'aliment ne contient pas de lactose. La formation d'acide $\omega$-muricholique, en remplacement de l'acide hyodésoxycholique, augmente quand la transformation bactérienne des acides biliaires diminue.

Des hypothèses sont présentées pour expliquer ces variations du métabolisme des acides biliaires sous l'action de l'aliment. 


\section{References}

ADRIAN J., 1974. Nutritional and Physiological consequences of the Maillard Reaction. WId. Rev. Nutr. Diet., 19, 71-122.

ADRIAN J., FRANGNE R., 1978. Rôle de la flore digestive dans l'adaptation du rat à une alimentation lactosée. J. int. Vitaminol. Nutr., 48, 170-176.

ARIES V., HILL M. J., 1970. Degradation of steroids by intestinal bacteria. Il. Enzymes catalysing the oxidoreduction of the $3 \alpha, 7 \alpha$ and $12 \alpha$ hydroxyl groups in cholic acid, and the dehydroxylation of the 7-hydroxyl group. Biochim. biophys. Acfa, 202, 535-543.

BALMER H., ZILVERSMIT D., 1974. Effects of diefary roughage on cholesterol absorption, cholesterol turn over and steroid excretion in the rat. J. Nutr., 104, 1319-1328.

FÉVRIER C., RÉRAT A., 1964. Influence du lactose sur la croissance et sur la composition corporelle du rat blanc. I. Relations avec le faux protidique de la ration. Ann. Biol. onim. Bioch. Biophys., 4, 423-439.

FISCHER J. E., 1957. Effect of feeding diets containing lactose upon $\beta$-D-galactosidase activity and organ development in the rat digestive tract. Amer. J. Physiol., 188, 49-53.

FOURNIER P., SUSBIELLE H., BESCOL-LIVERSAC J., 1959. Influence de la nature des composés glucidiques ingérés sur le développement de diverses parties du tube digestif du jeune rat. C. R. Acad. Sci. Paris, 248, 2799-2801.

KELLOGG T. F., 1971. Microbiological aspect of enterohepatic sterol and bile acid metabolism. Fed. Proc., 30, 1808-1814.

KELLOG T. F., 1974. Steroid balance and tissue cholesterol accumulation in germfree and conventional rats fed diets containing satured and polyunsaturated fats. J. Lipid Res., 15, 574-579.

KIM K. I., BENEVENGA N. J., GRUMMER R. H., 1978. Estimation of the fraction of the lactose in a high lactose diet available for fermentation in the caecum and colon of the rat. J. Nutr., 108, 79-89.

LEEGWATER D. C., DE GROOT A. P., VAN KALMOUT-KUYPER M., 1974. The aetiology of caecal enlargement in the rat. Fd. Cosmet. Toxicol., 12, 687-697.

MATHÉ D., LUTTON C., RAUTUREAU J., COSTE T., GOUFFIER E., SULPICE J. C., CHEVALLIER F., 1977. Effects of dietary fibers and salt mixtures on the cholesterol metabolism of rats. $J$. Nutr., 107, 466-474.

PANSU D., BELLATON C., BOSSHARD A., 1978. Effect of lactose feeding on cell renewal, disaccharidase activity and calcium-binding protein content in the intestinal mucosa of rats. Ann. Biol. anim. Bioch. Biophys., 18, 127-132.

RIOTTOT M., SACQUET E., MEJEAN C., LEPRINCE C., 1975. Effect of diet and microbial flora on intestinal absorption of sodium faurocholate in germfree and conventional rats. Nutr. Rep. Int., 12, 1-7.

RIOTTOT M., SACQUET E., LEPRINCE C., MEJEAN C., 1977. Effect of dietary lactose on the absorption of sodium taurocholate in the rat ileum. Nutr. Rep. Int., 15, 421-427.

SACQUET E., GARNIER H., RAIBAUD P., 1970. Etude de la vitesse du transit gastro-intestinal des spores d'une souche thermophile stricte de Bacillus subtilis chez le rat axénique, le rat holoxénique, le rat axénique cecectomisé. C. R. Soc. Biol., 164, 532-536.

SACQUET E., VAN HEIJENOORT Y., RIOTTOT M., LEPRINCE C., 1975. Action de la flore microbienne du tractus digestif sur le métabolisme des acides biliaires chez le rat. Biochim. biophys. Acto, 380, 52-65.

SACQUET E., MEJEAN C., LEPRINCE C., RIOTTOT M., RAIBAUD P., 1977a. Action du régime alimentaire et de la flore microbienne du tractus digestif sur le pool intestinal ef l'excrétion fécale des acides biliaires chez le rat. Ełude comparée chez des rats axéniques, gnotoxéniques et holoxéniques, Ann. Nutr. Alim., 30, 603-617.

SACQUET E., MEJEAN C., LEPRINCE C., RIOTTOT M., 1977b. Action de la flore microbienne du tractus digestif sur la biosynthèse de l'acide cholique. Biochim. biophys. Acta, 499, 67-72.

SACQUET E., LEPRINCE C., RIOTTOT M., MEJEAN C., LÉGLISE P., 1977c. Formation d'acide $\omega$-muricholique et excrétion fécale des acides biliaires chez le rat. C. R. Acad. Sci. Paris, Sér. $D, 284,557-559$. 
SACQUET E., LEPRINCE C., RIOTTOT M., MEJEAN C., RAIBAUD P., 1978a. Measurement of fecal bile acid excretion in gnotobiotic rats : comparison of gas-liquid chromatography and $\left(4-{ }^{14} \mathrm{C}\right)$ cholesterol isotopic equilibrium. Steroids, 32, 1-12.

SACQUET E., RAIBAUD P., MEJEAN C., RIOTTOT M., LEPRINCE C., LÉGLISE P., 1978b. Bacterial formation of $\omega$-muricholic acid in the rat (submiffed for publication to the Amer. Soc. Microbiol.

SCHEFFE H., 1959. The analysis of variance. Wiley J. and sons Inc., New York, London.

VAN HEIJENOORT Y., SACQUET E., RIOTTOT M., 1974. Dégradation bactérienne de l'acide $\beta$-muricholique chez le rat. Nutr. Metabol., 17, 65-73.

WOSTMANN B. S., 1973. Intestinal bile acids and cholesterol absorption in the germfree rat. J. Nutr., 103, 982-990.

WOTSMANN B., BRUCKNER-KARDOSS E., BEAVER M., CHANG L., MADSEN D., 1976. Effect of dietary lactose at levels comparable to human consumption on cholesterol and bile acid mefabolism of conventional and germfree rats. J. Nutr., 106, 1782-1790.

WOSTMANN B. S., BEAVER M., CHANG L., MADSON D., 1977. Effect of autoclaving a lactosecontaining diet on cholesterol and bile acid metabolism of conventional and germfree rats. Ann. J. clin. Nutr., 30, 1999-2005. 